\title{
Heavy Metals Accumulation in the Edible Vegetables of Lebanese Tabbouli Salad
}

\author{
Najoie Assaad ${ }^{1}$, Dani Fadel ${ }^{2}$, Ariadne Argyraki ${ }^{3}$, Zacharenia Kypritidou ${ }^{3}$, Adil Bakir $^{4}$ \& Elie Awad ${ }^{5}$ \\ ${ }^{1}$ Department of Languages and Literature, Faculty of Pedagogy, Lebanese University, New Rawda, Lebanon \\ ${ }^{2}$ Department of Plant Production, Faculty of Agriculture, Lebanese University, Dekwaneh, Lebanon \\ ${ }^{3}$ Faculty of Geology \& Geoenvironment, National \& Kapodistrian University of Athens, Athens, Greece \\ ${ }^{4}$ Geological and Environmental Laboratories (UPGE Labs), School of Earth \& Environmental Sciences, \\ University of Portsmouth, Portsmouth, UK \\ ${ }^{5}$ Department of Basic Sciences, Faculty of Agriculture, Lebanese University, Dekwaneh, Lebanon \\ Correspondence: Najoie Assaad, Department of Languages and Literature, Faculty of Pedagogy, Branch 2, \\ Lebanese University, New Rawda, Lebanon. Tel: 961-168-0193. E-mail: najoie.assaad@outlook.com
}

Received: April 16, 2020

doi:10.5539/jas.v12n7p155
Accepted: May 17, $2020 \quad$ Online Published: June 15, 2020

URL: https://doi.org/10.5539/jas.v12n7p155

\begin{abstract}
Nowadays soil contamination practices create hazardous environment impact that is a vital issue to prevent heavy metals from their integration in the food chain. Plant species selected for this study were the ingredients of the traditional Lebanese salad, Tabbouli, composed of parsley and lemon that were selected from Damour, olive and onion from Ghazir, peppermint and tomato from Akkar and bulgur, to fulfill all the requirements for the assessment of the major physicochemical properties and the contamination levels in vegetables from soils with heavy metal elements. The major physicochemical properties of topsoil including $\mathrm{pH}$, organic matter content method (LOI) and texture showed that studied soils were almost neutral $\mathrm{pH}$ of 7.09 with an organic matter content of $4.22 \%$ and a texture of sandy loam. Concentration ranges of $\mathrm{As}, \mathrm{Cu}, \mathrm{Fe}, \mathrm{Zn}, \mathrm{Mn}, \mathrm{Ni}, \mathrm{Ba}, \mathrm{Cd}, \mathrm{Co}, \mathrm{Cr}$, $\mathrm{Pb}$ and $\mathrm{P}$ in studied soil samples were determined and assessed by Inductively Coupled Plasma Optical Emission Spectroscopy, following aqua regia digestion and weak acetic acid digestion. Also, similar measurements on studied plant samples following microwave assisted digestion by $\mathrm{HNO}_{3} / \mathrm{H}_{2} \mathrm{O}_{2}$ were determined and transfer factors from soils to vegetables were accordingly calculated because of their health risk. Results showed that concentrations of most of studied elements in soil and plant samples were recorded above the permissible limits set by International standards for agricultural soils and by International standards for vegetables FAO/WHO. Furthermore, soil to plant transfer is the major path way of human exposure to potentially toxic elements contamination. Good manufacturing and agricultural practices and safety measurements have to be strictly adapted.
\end{abstract}

Keywords: pseudototal, mobilizable, assisted digestion, aqua regia, transfer factor

\section{Introduction}

Heavy metal contaminated vegetables refers to the excessive deposition and accumulation of potentially toxic elements (PTEs) such as cadmium $(\mathrm{Cd})$, lead $(\mathrm{Pb})$, chromium $(\mathrm{Cr})$ and arsenic (As), Zinc ( $\mathrm{Zn})$, copper $(\mathrm{Cu})$, nickel $(\mathrm{Ni})$, etc. in vegetables from soils. In Lebanon, soils may become contaminated through emissions from the rapidly expanding industrial areas, disposal of high metal wastes from electrical power stations, untreated wastewater sewage sludge, wastewater irrigation, land application of fertilizers, leaded gasoline and paints , pesticides, coal combustion residues and atmospheric deposition (Fadel et al., 2016; Nassif \& Saade, 2010). Studies on heavy metals type and content in the soil-plant system have gradually increased in recent years, resulting in posing risks and hazards to humans and ecosystem through direct ingestion or contact with contaminated soil, the food chain (soil-plant-human or soil-plant-animal-human), drinking of contaminated ground water, reduction in land usability for agricultural production, reduction in food quality and in causing food insecurity, and land tenure problems (Su et al., 2014).

Tabouli salad or Tabbouleh is a simple salad of very finely chopped vegetables composed of parsley, bulgur, onions, peppermint and tomato, parsley, all tossed with lime juice, olive oil, salt and peppers. In some Lebanese 
cities, Tabbouli is prepared by soaking the bulgur wheat in warm water for an hour to soften; in others, the bulgur is replaced by same amount of quinoa. Bulgur is the cereal food made from whole wheat partially boiled then dried, eaten in many recipes. Red or green onion (when available) is chopped with garlic very finely. Italian variety types of parsley (grown locally) is then chopped with some peppermint roughly until very finely and minced after discarding any large stems or stalks. The tomatoes are minced also very finely in cubic forms. All these ingredients are mixed along with the lemon juice, olive oil and peppers. When tasted, some salts may be added before serving fresh on the table (Fadel, 2010).

Tabouli salad is known to include iron, magnesium, zinc, calcium, phosphorus and copper in our diet. These minerals build and maintain strong bones, support the health of the immune system and aid in the synthesis of red blood cells. Because Tabouli is high in sodium, it is advised not to add salt when mixing its components for serving. Such food products are easily contaminated with heavy metals due to natural and anthropogenic activities (Adeniyi et al., 2011). A few heavy metals such as $\mathrm{Cd}, \mathrm{Pb}$ and As have been identified as the most toxic elements in the atmosphere as well as in soil and water (Smith et al., 1995). In the list of priority pollutants of US Environment Protection Agency (USEPA), heavy metals such as $\mathrm{Cd}, \mathrm{Pb}$ and As have been placed. Environment Protection Agency has placed $\mathrm{Cd}$ and $\mathrm{Pb}$ in group $\mathrm{B} 2$ indicated $\mathrm{Cd}$ and $\mathrm{Pb}$ being possible human carcinogens (Ahmed and Gülser, 2019). International Agency for Research on Cancer (IARC) has classified Cd compounds as carcinogenic to human (Group 1) and inorganic $\mathrm{Pb}$ compounds (Group 2A) as probably carcinogenic to human. Similarly, $\mathrm{Pb}$ has been classified as possibly carcinogenic to human (Group 2B) and As has been placed in group A by USEPA (Kim et al., 2015). Hence, it is undoubtedly noticed that the contamination of vegetables by heavy metals should be determined with great priority based on the assessment of health risks (Latif et al., 2018). It is also known that the degree of accumulation of heavy metals depends on the soil type, plant species, growth condition of the plant, presence of other ions in the soils (Fadel et al., 2016). The present study was conducted in order to determine the total and available heavy metals or the potentially toxic elements (PTEs) in the soils of the commonly grown vegetables used in Tabbouli salad ingredients after acid digestion and to determine the concentration of these heavy metals in the edible parts of the same vegetables. Also, the transfer factors of these heavy metals from soils to vegetables were accordingly calculated because of their health risk.

\section{Material and Methods}

\subsection{Field Sampling and Treatment of Topsoil and Vegetable Samples}

The soil and vegetable samples for Tabbouli salad ingredients, were collected in the spring of 2018 from three communal allotments (area site, coordinates) within site A for parsley and lemon (Damour, 33 ${ }^{\circ} 43^{\prime} 19.1^{\prime \prime} \mathrm{N}$ $35^{\circ} 27^{\prime} 11.7^{\prime \prime} \mathrm{E} 33.721981,35.453260$ ), site B for olive and onion (Ghazir, 34 $01^{\prime} 06.7^{\prime \prime} \mathrm{N}, 35^{\circ} 41^{\prime} 03.3^{\prime \prime} \mathrm{E}$, $34.018535,35.684238$ ) and site $\mathrm{C}$ for peppermint and tomato (Akkar, $34^{\circ} 32^{\prime} 44.7^{\prime \prime} \mathrm{N}, 36^{\circ} 04^{\prime} 54.5^{\prime \prime} \mathrm{E}, 34.545737$, 36.081791). All vegetable samples were separately oven dried at $45^{\circ} \mathrm{C}$ for 3 days in a thermostatically controlled oven and kept for further analysis in the laboratory of soil sciences of the Faculty of Agriculture in the Lebanese University. Additionally, the only consumable parts of related vegetable samples were selected and washed primarily with tap water and then with deionized water, so as to remove any soil and dirt particles In the traditional Lebanese cuisine, a net hundred gram of "Tabbouli" plate (DW basis) was found to be made up also in our laboratory from the following quantities of $425 \mathrm{~g}$ fresh vegetables (per gram fresh weight): parsley (80), bulgur (9), lemon (28), olive (28), onion (30), peppermint (10) and tomato (280), the ingredients were partially dried in air and cut down into small pieces with a knife of stainless steel. Bulgur is the cereal food made from the cracked parboiled groats of several durum wheat species.

The soil samples were collected in plastic bags, air dried, disaggregated and sieved to a $2 \mathrm{~mm}$ fraction in the Faculty of Geology and Geoenvironment, in the National and Kapodistrian University of Athens. All soil and plant samples were also ground in an agate mill $(<2 \mu \mathrm{m}$ diameter $)$.

\subsection{Chemical Analysis of Soil and Vegetable Samples}

The major physicochemical properties of the related soil samples of Tabbouli ingredients including $\mathrm{pH}$, organic matter content (TOC $\times 1.72$ ) method by heating $1 \mathrm{~g}$ of each sample to $4500{ }^{\circ} \mathrm{C}$ for 4 hours in a furnace oven) and texture or grain size distribution using Bouyoucos Hydrometer Method (Bouyoucos, 1962) were assessed (Fadel et al., 2016). The total elemental concentrations of plants were measured by Inductively Coupled Plasma Optical Emission Spectroscopy (ICP-OES) in the University of Portsmouth, UK following microwave digestion by $\mathrm{HNO}_{3} / \mathrm{H}_{2} \mathrm{O}_{2}, 6: 1 \mathrm{v} / \mathrm{v}$. The pseudo-total elemental concentration of soil samples was measured by aqua regia digestion $\left(\mathrm{HNO}_{3}-\mathrm{H}_{2} \mathrm{O}_{2}-\mathrm{HCl}\right)$ (US-EPA, 2002). The mobile elemental content of the soils was determined by weak extraction using acetic acid $(0.43 \mathrm{M})$ after mixing $1 \mathrm{~g}$ of the soil samples (less than $2 \mu \mathrm{m}$ diameter) with 40 $\mathrm{ml}$ of $0.43 \mathrm{M} \mathrm{HAc}$ and shaking for $16 \mathrm{~h}$ at room temperature in an overhead shaker (Groenenberg et al., 2017). 


\subsection{Data Analysis and Quality Control}

The descriptive statistics of the accumulation of heavy metals concentrations (mean, median, standard deviation, relative standard deviation, minimum and maximum) were determined. The extractability percentages of each element were estimated and were presented in terms of the ISO 9001: 2015 in accordance with the requirements of the quality assurance system. Water Certified Reference Material or Water (CRM), Plant CRM (Recovery percentage range $\sim 100 \%$ ), Aqua Regia Soil Digestion (Recovery percentage range $\sim 100 \%$ ) were assessed with a significance level $<0.05$. Transfer factors from soils to vegetables were calculated. The analytical quality control procedures included the performance of triplicate analysis, the inclusion of blank solutions and certified reference materials of soils (NIST SRM 2709 and NIST SRM2711a for the total analysis and BCR-483 and BCR-484 for the acetic acid extraction) at random positions within the analytical batches. The obtained results from analytical control were found within acceptable limits for all geochemical results.

\section{Results and Discussion}

\subsection{Characterization of Soil}

The statistical summary of physicochemical properties including $\mathrm{pH}$, total carbon (TOC) and texture (sand, silt, clay\%) of investigated soil samples are shown in Table 1. The $\mathrm{pH}$ values of soil samples ranged from 6.5 to 7.55 (neutral). The OM average percentage value of $5 \%$ was considered very high for urban agriculture soils. Most of soil textures were sandy loam (means of sand and clay were 70 and $4 \%$, respectively). The minimum sand percentage was 40.72 giving a silt loam texture to soils grown with onions and the maximum sand percentage was 86.72 giving a fine sandy texture to soils grown with olive for olive oil. For example, tomatoes grow in any of all these well drained soils.

Table 1. Physicochemical characteristics (pH and organic matter) and texture of the examined soil samples) in respect to the cultivated vegetation in communal allotments of Damour, Ghazir or Akkar areas

\begin{tabular}{llllllll}
\hline Sampling site & Soil Vegetation & OM\% & PH & Sand\% & Silt\% & Clay\% & Soil texture \\
\hline Damour & Parsley & 5.00 & 7.50 & 71.7 & 19.6 & 8.65 & Sandy loam \\
Damour & Lemon & 3.24 & 7.49 & 40.72 & 57.2 & 2.08 & Silt loam \\
Ghazir & Olive & 3.21 & 7.10 & 86.72 & 9.2 & 4.08 & Fine sand \\
Ghazir & Onion & 4.36 & 6.50 & 70.72 & 27.2 & 2.08 & Sandy loam \\
Akkar & Peppermint & 4.12 & 7.44 & 65.4 & 30.52 & 4.08 & Sandy loam \\
Akkar & Tomato & 4.60 & 7.45 & 70.4 & 25.2 & 4.08 & Sandy loam \\
\hline
\end{tabular}

The pseudototal PTEs concentrations of the soil samples, in respect to the type of cultivated vegetation are given in Table 2. Mean values of the pseudototal elemental extractable concentrations in soils were in the following decreasing order: $\mathrm{Fe}>\mathrm{Mn}>\mathrm{Zn}>\mathrm{Cu}>\mathrm{Ba}>\mathrm{Pb}>\mathrm{Co}>\mathrm{Cr}>\mathrm{Ni}>\mathrm{As}>\mathrm{Cd}$. The Damour soil samples (parsley and lemon cultivated in sandy loam and silt loam soils) exhibited the highest $\mathrm{Zn}, \mathrm{Ni}$ and $\mathrm{Cu}$ concentrations. Lemon soils were characterized by the highest $\mathrm{Ni}$ and $\mathrm{Cu}$ concentrations exceeding the intervention values of Dutch List in Table 2 (Dutch Ministry of Infrastructure and Water Management, 2009). Compared to the Canadian standards for agricultural soils (Ministry of Environment, 2009), the mean concentration values are elevated for $\mathrm{Co}, \mathrm{Cd}$, and $\mathrm{Pb}$; PTEs that are highly related to human activities. Moreover, in contrast to other related studies, no significant correlations were detected between the key soil properties and the pseudototal concentrations of heavy metals (Rodrigues et al., 2009). This may be due to soil $\mathrm{pH}$ closed to neutral associated with high organic matter content in the studied samples. 
Table 2. Pseudototal PTE concentrations of soil samples (in $\mathrm{mg} / \mathrm{kg}$ of dry matter) in respect to the cultivated vegetation, in comparison with international standards for agricultural soils

\begin{tabular}{|c|c|c|c|c|c|c|c|c|c|c|c|}
\hline Pseudototal PTE Soil Vegetation & Zn & Co & $\mathbf{N i}$ & $\mathbf{C u}$ & $\mathbf{P b}$ & Cd & $\mathrm{Cr}$ & As & $\mathbf{B a}$ & $\mathbf{F e}$ & Mn \\
\hline Parsley & 546.9 & 38.4 & 20.0 & 36.9 & 72.0 & 3.0 & 40.1 & 7.4 & 91.7 & 3503.3 & 2068.9 \\
\hline Bulgur & 48.1 & 50.3 & 21.4 & 159.7 & 141.8 & 1.7 & 53.6 & 38.4 & 100.9 & 7642.8 & 2102.6 \\
\hline Lemon & 45.3 & 60.7 & 166.5 & 1275.3 & 175.8 & 0.3 & 48.7 & 4.5 & 349.7 & 1141.0 & 1623.9 \\
\hline Olive & 75.2 & 45.2 & 13.0 & 6.9 & 80.7 & 0.3 & 25.6 & 1.1 & 85.3 & 368.7 & 1552.5 \\
\hline Onion & 256.7 & 76.1 & 1.7 & 145.0 & 67.6 & 1.7 & 30.0 & 13.9 & 101.1 & 354.4 & 1582.1 \\
\hline Peppermint & 125.8 & 54.5 & 0.8 & 1.4 & 77.3 & 2.4 & 70.4 & 6.7 & 91.6 & 115.3 & 672.1 \\
\hline Tomato & 187.7 & 40.2 & 3.9 & 56.7 & 76.4 & 1.7 & 61.4 & 2.7 & 450.8 & 199.3 & 801.4 \\
\hline \multicolumn{12}{|l|}{ Descriptive statistics } \\
\hline Mean (mg/kg) & 229.1 & 50.5 & 30.9 & 214.8 & 95.4 & 1.8 & 46.2 & 10.3 & 170.3 & 2103.5 & 1559.0 \\
\hline Median (mg/kg) & 156.7 & 47.7 & 16.5 & 46.8 & 76.9 & 1.7 & 44.4 & 7.1 & 96.3 & 754.9 & 1603.0 \\
\hline $\mathrm{STD}(\mathrm{mg} / \mathrm{kg})$ & 208.9 & 13.1 & 55.5 & 432.5 & 40.3 & 1.1 & 15.3 & 12.0 & 144.5 & 2650.5 & 558.2 \\
\hline RSD (\%) & 91.2 & 26.0 & 179.4 & 201.3 & 42.2 & 61.1 & 33.1 & 116.9 & 84.8 & 126.0 & 35.8 \\
\hline $\operatorname{Max}(\mathrm{mg} / \mathrm{kg})$ & 546.9 & 76.1 & 166.5 & 1275.3 & 175.8 & 3.0 & 70.4 & 38.4 & 450.8 & 7642.8 & 2102.6 \\
\hline $\operatorname{Min}(\mathrm{mg} / \mathrm{kg})$ & 45.3 & 38.4 & 0.8 & 1.4 & 67.6 & 0.3 & 25.6 & 1.1 & 85.3 & 115.3 & 672.1 \\
\hline \multicolumn{12}{|l|}{ International standards for agricultural soils } \\
\hline Deutch intervention values ${ }^{a}$ & 720 & 190 & 100 & 190 & 530 & 13 & & 76 & & & \\
\hline Ontario standards for agricultural soils ${ }^{\mathrm{b}}$ & 290 & 19 & 37 & 62 & 45 & 1 & 67 & 11 & 210 & & \\
\hline
\end{tabular}

Note. ${ }^{\text {a }}$ Soil remediation circular $2009 ;{ }^{b}$ Ontario guidelines for agricultural soils.

The mobile PTEs concentrations of the soil samples, in respect to the type of cultivated vegetation are given in Table 3. Mean values of the mobile elemental concentrations in soils were in the following decreasing order $\mathrm{Mn}>$ $\mathrm{Zn}>\mathrm{Ba}>\mathrm{Co}>\mathrm{Fe}>\mathrm{Pb}>\mathrm{Cr}>\mathrm{As}>\mathrm{Cd}$ showing that $\mathrm{Mn}, \mathrm{Zn}$, Co or $\mathrm{Pb}$ and $\mathrm{Cd}$ we decreasing accordingly regardless the soil texture from their extractable phases into their mobile phases. Box plots of extractability ratios of the studied elements in soils and plants are given in Figure 1, based on pseudototal and dilute acetic acid extractable concentrations. The elements are ordered according to decreasing median value (horizontal lines). Box plots show that $\mathrm{Zn}$, Co and Mn exhibited elevated mobile concentrations indicating their presence in the easily extractable fraction (Kelepertzis \& Argyraki, 2015) and a high availability for plant uptake. On the other hand, the mobile concentrations of the rest PTEs was lower than their pseudototal amount, implying their presence in more stable phases, associated mainly to Fe-oxides. Ni was undetected in the mobile fraction of most soils. Manganese presented the highest extractability ratio while Fe was hardly extractable by the dilute acetic acid. The low extractability ratio of $\mathrm{Cu}$ was also worth noting as if combined with the relatively low pseudototal concentrations in soil might be indicative of $\mathrm{Cu}$ deficiency in the plants grown in the study area.

Table 3. Mobile PTEs concentrations (in $\mathrm{mg} / \mathrm{kg}$ of dry matter) of soil samples in respect to the type of cultivated vegetation (bdl: below detection limit)

\begin{tabular}{llllllllllll}
\hline Mobile PTE Soil Vegetation & Zn & Co & Ni & Cu & Pb & Cd & Cr & As & Ba & Fe & Mn \\
\hline Parsley & 514.6 & 57.5 & bdl & 16.2 & 15.4 & 2.4 & 4.1 & 1.0 & 21.6 & 63.9 & 1032.7 \\
Bulgur & 659.3 & 24.4 & bdl & 0.1 & 3.5 & 1.3 & 13.0 & 4.7 & 189.0 & 21.4 & 449.7 \\
Lemon & 426.8 & 32.5 & bdl & bdl & 3.6 & 0.1 & 33.1 & 3.9 & 180.1 & 37.0 & 630.3 \\
Olive & 218.6 & 252.3 & bdl & 1.7 & 10.4 & 1.0 & 24.4 & 1.1 & 32.0 & 60.7 & 1114.0 \\
Onion & 331.1 & 51.1 & bdl & 33.4 & 11.2 & 2.0 & 9.5 & 7.7 & 55.9 & 36.0 & 1975.6 \\
Peppermint & 192.1 & 218.3 & 18.8 & 2.4 & 60.3 & 1.3 & 4.9 & 3.3 & 40.9 & 33.6 & 3788.9 \\
Tomato & 438.6 & 151.0 & 2.5 & 2.3 & 65.3 & 1.4 & 6.5 & 2.8 & 362.9 & 58.5 & 3531.0 \\
Descriptive statistics & & & & & & & & & & \\
Mean $(\mathrm{mg} / \mathrm{kg})$ & 412.0 & 105.6 & - & 10.3 & 23.1 & 1.5 & 12.5 & 3.2 & 113.0 & 46.9 & 1694.3 \\
Median $(\mathrm{mg} / \mathrm{kg})$ & 432.7 & 57.5 & - & 2.4 & 13.3 & 1.3 & 8.0 & 3.0 & 48.4 & 47.7 & 1073.3 \\
STD $(\mathrm{mg} / \mathrm{kg})$ & 158.3 & 89.3 & - & 11.9 & 24.9 & 0.8 & 10.8 & 2.3 & 122.1 & 16.7 & 1294.7 \\
RSD $(\%)$ & 38.4 & 84.6 & - & 115.7 & 107.7 & 53.2 & 86.4 & 73.2 & 108.1 & 35.6 & 76.4 \\
Max $(\mathrm{mg} / \mathrm{kg})$ & 659.3 & 252.3 & 18.8 & 33.4 & 65.3 & 2.4 & 33.1 & 7.7 & 362.9 & 63.9 & 3788.9 \\
Min $(\mathrm{mg} / \mathrm{kg})$ & 192.1 & 24.4 & 2.5 & 0.1 & 3.5 & 0.1 & 4.1 & 1.0 & 21.6 & 21.4 & 449.7 \\
\hline
\end{tabular}



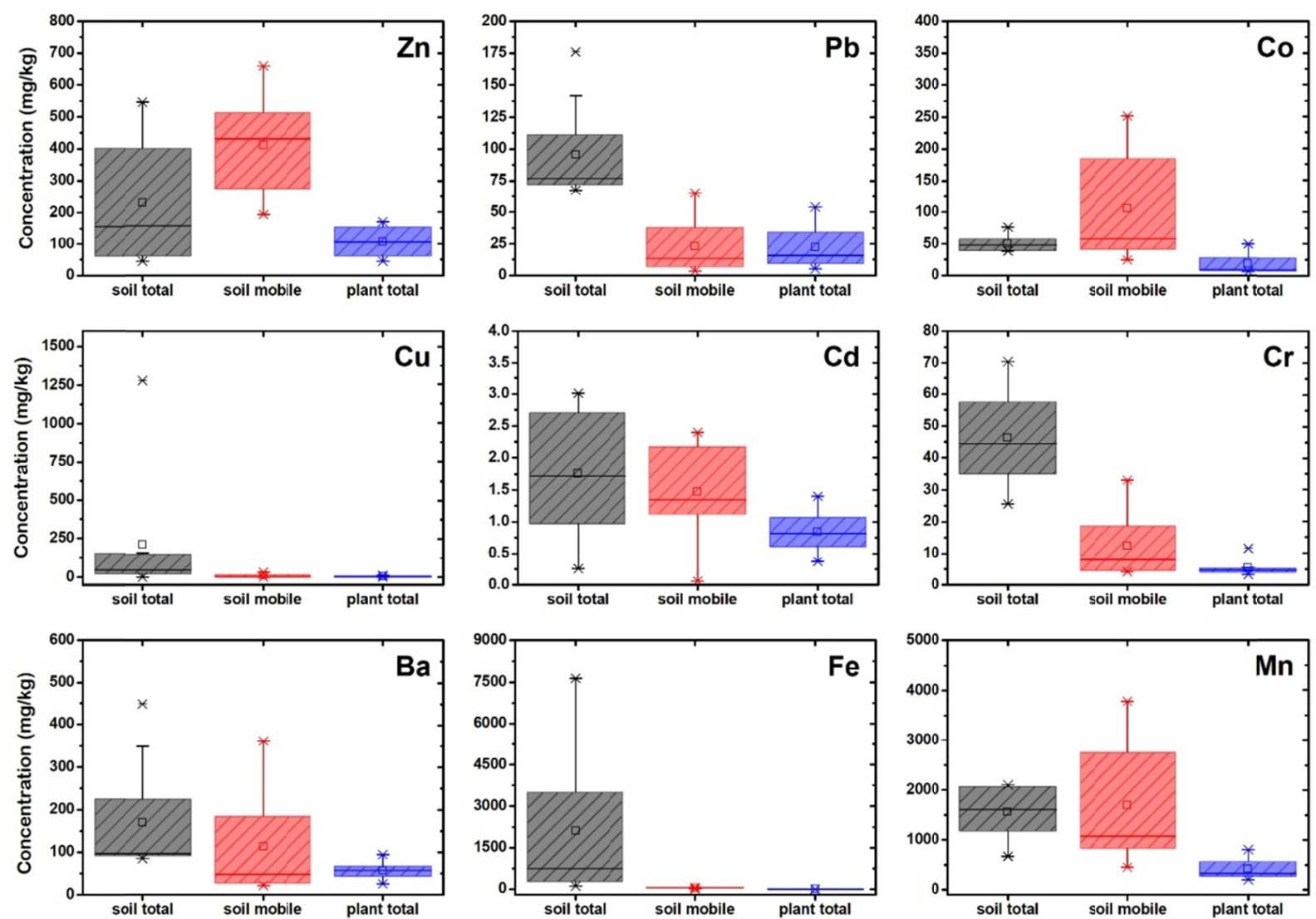

Figure 1. Box plots of extractability ratios of the studied elements (from upper left to lower right: $\mathrm{Zn}, \mathrm{Pb}, \mathrm{Co}, \mathrm{Cu}$, $\mathrm{Cd}, \mathrm{Cr}, \mathrm{Ba}, \mathrm{Fe}$ and $\mathrm{Mn}$ ) in soil (plant total and soil mobile) and plant samples (plant total), based on pseudototal (soil total) and dilute acetic acid extractable concentrations (soil mobile). The elements are ordered according to decreasing median value (horizontal lines) and concentrations $(\mathrm{mg} / \mathrm{kgDW})$

\subsection{PTE Concentrations in Plants}

Table 4 shows the amount of PTEs in the plant extracts. Parsley (Petroselinum crispum, Apiaceae) is an annual herb, which is important dietary source of vitamins and essential metals. Its usage at sufficient levels whether cooked or not cooked can promote the levels of vitamins and essential metals in human body, which in turn can decrease the risks of $\mathrm{Cd}$ toxicity (Zhai et al., 2015). Mean values of the elemental extractable concentrations in plants were in the following decreasing order $\mathrm{Mn}>\mathrm{Zn}>\mathrm{Ba}>\mathrm{Ni} \mathrm{Pb}>\mathrm{Co}>\mathrm{Cr}>\mathrm{Cu}>\mathrm{Fe}>\mathrm{As}>\mathrm{Cd}$, almost similar to that in mobile elemental concentrations in soils with the $\mathrm{Mn}, \mathrm{Zn}, \mathrm{Cu}$, As and $\mathrm{Cd}$. Compared to the International standards for vegetables $\mathrm{FAO} / \mathrm{WHO}$ guideline values, the mean concentration values of $\mathrm{Ni}, \mathrm{Pb}, \mathrm{Ba}$ and Mn show that Good Manufacturing Practice (GMP) and/or Good Agricultural Practice (GAP) have to be strictly adapted in order to control such a contamination problem in studied vegetables used in Tabbouli. Parsely exhibited the highest $\mathrm{Zn}, \mathrm{Cu}$ and $\mathrm{Fe}$ values. Olives show high concentrations of $\mathrm{Co}, \mathrm{Ni}$, and $\mathrm{Pb}$. $\mathrm{Ni}$ is favored in peppermint tissues and $\mathrm{Cr}$ in lemons. The mobile $\mathrm{Pb}$ fraction in both soil and plants are identical, implying the high mobility of the element (Figure 1). 
Table 4. PTE concentrations in the plant samples $(\mathrm{mg} / \mathrm{kg}$ in dry matter) in comparison with international standards for vegetables FAO/WHO guideline values

\begin{tabular}{|c|c|c|c|c|c|c|c|c|c|c|c|}
\hline PTE plant samples & $\mathbf{Z n}$ & Co & $\mathbf{N i}$ & $\mathbf{C u}$ & $\mathbf{P b}$ & Cd & $\mathrm{Cr}$ & As & $\mathbf{B a}$ & $\mathbf{F e}$ & Mn \\
\hline Parsley & 169.1 & 9.3 & 25.8 & 11.3 & 5.1 & 0.8 & 4.0 & 0.9 & 59.9 & 4.3 & 329.9 \\
\hline Bulgur & 62.0 & 9.5 & 28.4 & 1.1 & 15.3 & 0.8 & 5.1 & 0.2 & 54.3 & 1.4 & 484.1 \\
\hline Lemon & 61.2 & 6.1 & 21.9 & 0.6 & 23.5 & 0.7 & 11.6 & 0.5 & 46.5 & 2.5 & 284.2 \\
\hline Olive & 44.7 & 31.3 & 25.3 & 1.3 & 53.8 & 0.4 & 4.8 & 0.4 & 25.6 & 4.0 & 201.1 \\
\hline Onion & 87.7 & 6.5 & 19.8 & 6.0 & 44.8 & 0.5 & 3.3 & 5.1 & 39.9 & 2.4 & 256.3 \\
\hline Peppermint & 124.6 & 50.3 & 62.6 & 2.2 & 13.9 & 1.4 & 4.7 & 6.2 & 94.7 & 2.2 & 805.2 \\
\hline Tomato & 136.7 & 25.5 & 52.3 & 2.2 & 16.6 & 1.3 & 5.6 & 6.6 & 74.0 & 3.9 & 649.5 \\
\hline \multicolumn{12}{|l|}{ Descriptive statistics } \\
\hline mean $(\mathrm{mg} / \mathrm{kg})$ & 106.9 & 18.5 & 32.7 & 4.5 & 22.3 & 0.8 & 5.4 & 2.6 & 56.9 & 3.1 & 417.5 \\
\hline median $(\mathrm{mg} / \mathrm{kg})$ & 106.1 & 9.4 & 25.8 & 2.2 & 16.0 & 0.8 & 4.7 & 0.9 & 57.1 & 3.2 & 329.9 \\
\hline $\mathrm{STD}(\mathrm{mg} / \mathrm{kg})$ & 49.7 & 15.9 & 15.7 & 4.5 & 17.9 & 0.3 & 2.6 & 2.8 & 21.1 & 1.1 & 212.0 \\
\hline RSD (\%) & 46.5 & 86.3 & 48.0 & 99.6 & 80.4 & 41.5 & 48.8 & 109.9 & 37.2 & 35.6 & 50.8 \\
\hline $\max (\mathrm{mg} / \mathrm{kg})$ & 169.1 & 50.3 & 62.6 & 11.3 & 53.8 & 1.4 & 11.6 & 6.6 & 94.7 & 4.3 & 805.2 \\
\hline $\min (\mathrm{mg} / \mathrm{kg})$ & 44.7 & 6.1 & 19.8 & 0.6 & 5.1 & 0.4 & 3.3 & 0.2 & 25.6 & 1.4 & 201.1 \\
\hline \multicolumn{12}{|c|}{ International standards for vegetables $F A O / W H O$ guideline values } \\
\hline $\max (\mathrm{mg} / \mathrm{kg})$ & 160 & 10 & 3.7 & 45.8 & 3 & 2 & $0.006-18$ & 5 & 2 & 2486 & 100 \\
\hline
\end{tabular}

A net hundred gram of "Tabbouli" plate (DW basis is made up of the following quantities of $425 \mathrm{~g}$ fresh vegetables (per gram fresh weight): parsley (80), bulgur (9), lemon (28), olive (28), onion (30), peppermint (10) and tomato (240). Bulgur is a cereal food made from the cracked parboiled groats of several durum wheat species in Lebanon. The concentrations of heavy metals in analyzed vegetable samples were higher than the FAO/WHO guideline values of $0.1-0.2 \mathrm{mg} / \mathrm{kg} \mathrm{Cr}, 0.3 \mathrm{mg} / \mathrm{kg} \mathrm{Fe} ; 0.1 \mathrm{mg} / \mathrm{kg} \mathrm{Pb} ; 0.1 \mathrm{mg} / \mathrm{kg} \mathrm{Cu} ; 0.1 \mathrm{mg} / \mathrm{kg} \mathrm{Zn;} 0.1$ $\mathrm{mg} / \mathrm{kg} \mathrm{Ni} ; 0.02 \mathrm{mg} / \mathrm{kg} \mathrm{Cd}$ and $0.3 \mathrm{mg} / \mathrm{kg} \mathrm{Mn}$. The maximum value of heavy metal element $\mathrm{Zn}, \mathrm{Cu}, \mathrm{Ni}, \mathrm{Cr}, \mathrm{Co}$, $\mathrm{Mn}, \mathrm{Fe}, \mathrm{Ba}, \mathrm{Pb}, \mathrm{Cd}, \mathrm{As})$ concentration $(\mathrm{mg} / 100 \mathrm{~g} \mathrm{DW})$ in every Tabbouli salad ingredient (parsley, parsley, bulgur, lemon, olive, onion, peppermint and tomato) is shown in Table 5.

Table 5. The amount of PTEs ( $\mathrm{mg}$ ) of each vegetable used in a $100 \mathrm{~g}(\mathrm{mg} / \mathrm{g}$ in dry matter) of Tabbouli salad

\begin{tabular}{lllllllll}
\hline Element & $\begin{array}{l}\text { Parsley } \\
(\mathbf{m g} / \mathbf{8 0} \mathbf{g})\end{array}$ & $\begin{array}{l}\text { Bulgur } \\
(\mathbf{m g} / \mathbf{9})\end{array}$ & $\begin{array}{l}\text { Lemon } \\
(\mathbf{m g} / \mathbf{2 8} \mathbf{g})\end{array}$ & $\begin{array}{l}\text { Olive } \\
\mathbf{( m g / 2 8} \mathbf{g})\end{array}$ & $\begin{array}{l}\text { Onion } \\
(\mathbf{m g} / \mathbf{3 0} \mathbf{g})\end{array}$ & $\begin{array}{l}\text { Peppermint } \\
(\mathbf{m g} / \mathbf{1 0} \mathbf{g})\end{array}$ & $\begin{array}{l}\text { Tomato } \\
(\mathbf{m g} / \mathbf{2 8 0} \mathbf{g})\end{array}$ & $\begin{array}{l}\text { Total } \\
(\mathbf{m g} / \mathbf{1 0 0} \mathbf{g})\end{array}$ \\
\hline $\mathrm{Zn}$ & 13.53 & 0.56 & 1.22 & 1.25 & 2.63 & 1.25 & 38.27 & 13.8 \\
$\mathrm{Co}$ & 0.74 & 0.09 & 0.12 & 0.88 & 0.19 & 0.50 & 7.15 & 2.3 \\
$\mathrm{Ni}$ & 2.06 & 0.26 & 0.44 & 0.71 & 0.59 & 0.63 & 14.63 & 4.5 \\
$\mathrm{Cu}$ & 0.90 & 0.01 & 0.01 & 0.04 & 0.18 & 0.02 & 0.62 & 0.4 \\
$\mathrm{~Pb}$ & 0.41 & 0.14 & 0.47 & 1.51 & 1.34 & 0.14 & 4.65 & 2.0 \\
$\mathrm{Cd}$ & 0.07 & 0.01 & 0.01 & 0.01 & 0.02 & 0.01 & 0.36 & 0.1 \\
$\mathrm{Cr}$ & 0.32 & 0.05 & 0.23 & 0.13 & 0.10 & 0.05 & 1.56 & 0.6 \\
$\mathrm{As}$ & 0.07 & 0.00 & 0.01 & 0.01 & 0.15 & 0.06 & 1.85 & 0.5 \\
$\mathrm{Ba}$ & 4.79 & 0.49 & 0.93 & 0.72 & 1.20 & 0.95 & 20.73 & 7.0 \\
$\mathrm{Fe}$ & 0.34 & 0.01 & 0.05 & 0.11 & 0.07 & 0.02 & 1.09 & 0.4 \\
$\mathrm{Mn}$ & 26.40 & 4.36 & 5.68 & 5.63 & 7.69 & 8.05 & 181.87 & 56.4 \\
\hline
\end{tabular}

One approach to assess the mobility of potentially toxic elements by plants is to calculate the transfer factor (TF), as defined in the following equation (Chojnacka et al., 2005):

$$
\mathrm{TF}=\frac{\mathrm{C}_{\text {plant }}}{\mathrm{C}_{\text {total soil }}}
$$

where, $\mathrm{C}_{\text {plant }}$ is the concentration of an element in the plant material (dry weight basis) and $\mathrm{C}_{\text {total }}$ is the total concentration of the same element in the soil (dry weight basis) where the plant was grown. The higher the value of the TF, the more mobile/available the element is. The TF values of the elements for the plants studied are presented in Table 6. 
If the ratios $>1$, the plants have accumulated elements, the ratios around 1 indicate that the plants are not influenced by the elements, and ratios $<1$ show that plants exclude the elements from the uptake (Olowoyo et al., 2010).

Table 6. Transfer factors (TF) of selected PTEs from soil to the vegetables in Tabbouli salad

\begin{tabular}{|c|c|c|c|c|c|c|c|c|c|c|c|}
\hline \multirow{2}{*}{ Plant Sample } & \multicolumn{11}{|c|}{$T F$} \\
\hline & $\mathrm{Zn}$ & $\mathrm{Co}$ & $\mathrm{Ni}$ & $\mathrm{Cu}$ & $\mathrm{Pb}$ & $\mathrm{Cd}$ & $\mathrm{Cr}$ & As & $\mathrm{Ba}$ & $\mathrm{Fe}$ & $\mathrm{Mn}$ \\
\hline Parsley & 0.31 & 0.24 & 1.29 & 0.31 & 0.07 & 0.28 & 0.10 & 0.12 & 0.65 & 0.00 & 0.16 \\
\hline Cucumber & 0.31 & 0.24 & 1.29 & 0.31 & 0.07 & 0.28 & 0.10 & 0.12 & 0.65 & 0.00 & 0.16 \\
\hline Bulgur & 1.29 & 0.19 & 1.33 & 0.01 & 0.11 & 0.47 & 0.09 & 0.00 & 0.54 & 0.00 & 0.23 \\
\hline Lemon & 1.35 & 0.10 & 0.13 & 0.00 & 0.13 & 2.53 & 0.24 & 0.10 & 0.13 & 0.00 & 0.18 \\
\hline Olive & 0.59 & 0.69 & 1.95 & 0.20 & 0.67 & 1.43 & 0.19 & 0.38 & 0.30 & 0.01 & 0.13 \\
\hline Onion & 0.34 & 0.09 & 11.55 & 0.04 & 0.66 & 0.31 & 0.11 & 0.37 & 0.39 & 0.01 & 0.16 \\
\hline Peppermint & 0.99 & 0.92 & 78.10 & 1.62 & 0.18 & 0.58 & 0.07 & 0.92 & 1.03 & 0.02 & 1.20 \\
\hline Tomato & 0.73 & 0.63 & 13.47 & 0.04 & 0.22 & 0.76 & 0.09 & 2.45 & 0.16 & 0.02 & 0.81 \\
\hline
\end{tabular}

According to Table $6, \mathrm{Ni}$ is highly accumulated in most of studied plants, mainly in peppermint $(\mathrm{TF}=78.1)$, tomatoes $(\mathrm{TF}=13.47)$ and onions $(\mathrm{TF}=11.55)$.

\section{Conclusions}

The health outcomes of consuming contaminated vegetables by the public is necessary for responsible authorities to take proper measures, especially on the studied sites with very high levels of heavy metals. Our study shows that Cadmium, $\mathrm{Ni}$ and $\mathrm{Pb}$ in Tabbouli salad highly exceed the permissible intake daily limit, the 0.1 $\mathrm{mg}, 1.4 \mathrm{mg}$ and $0.245 \mathrm{mg}$, respectively per day for a $70 \mathrm{~kg}$ adult. Cadmium in such high concentrations may cause renal damages, decrease in bone calcium concentrations and can affect reproduction. Ni in such high concentrations may cause damages to DNA and cell structures. $\mathrm{Pb}$ in such high concentrations may cause nervous, liver, kidneys, spleen and lung diseases. Good Manufacturing Practice and Good Agricultural Practice (GAP) have to be strictly adapted in order to control the plant growth and development with acceptable levels of heavy metal concentrations.

\section{References}

Adeniyi, A. A., Owoade, J., Shotonwa, I. O., Okedeyi, O. O., Ajibade, A. A., Sallu, A. R., ... Ope, K. A. (2011). Monitoring metals pollution using water and sediments collected from Ebute Ogbo river catchments, Ojo, Lagos, Nigeria. African Journal of Pure and Applied Chemistry, 5(8), 219-223.

Ahmed, A. N., \& Gülser, F. (2019). Industry caused heavy metal pollution in the soils of North-Iraq. Environmental Bulletin, 28(2A), 1057-1064.

Bouyoucos, G. J. (1962). Hydrometer Method Improved for Making Particle Size Analysis of Soils. Agronomy Journal, 54, 464-465. https://doi.org/10.2134/agronj1962.00021962005400050028x

Deutch Ministry of Infrastructure and Water Management. (2009). Soil Remediation Circular, 2009.

Fadel, D., Argyraki, A., Papageorgiou, S., \& Kelepertzis, E. (2016). Heavy metals in cultivated soil and plants of Damour urban area-Lebanon. Bulletin of the Geological Society of Greece, 50, 2108-2117. https://doi.org/ 10.12681/bgsg. 14262

Fadel, J. (2010). You want to cook, just follow the book. Dar el Moufid, 5(4), 233-266.

Groenenberg, J. E., Römkens, P. F. A. M., Van Zomeren, A., Rodrigues, S. M., \& Comans, R. N. J. (2017). Evaluation of the Single Dilute $(0.43 \mathrm{M})$ Nitric Acid Extraction to Determine Geochemically Reactive Elements in Soil. Environmental Science \& Technology, 51(4), 2246-2253. https://doi.org/10.1021/acs.est. 6b05151

Kelepertzis, E., \& Argyraki, A. (2015). Geochemical associations for evaluating the availability of potentially harmful elements in urban soils: Lessons learnt from Athens, Greece. Applied Geochemistry, 59, 63-73. https://doi.org/10.1016/j.apgeochem.2015.03.019

Kim, H. S., Kim, Y. J., Seo, Y. R. (2015). An Overview of Carcinogenic Heavy Metal: Molecular Toxicity Mechanism and Prevention. Journal of Cancer Prevention, 4, 232-240. https://doi.org/10.15430/JCP.2015. 20.4.232 
Latif, A., Bilal, M., Asghar, W., Azeem, M., Ahmad, M. I., Abbas, A., ... Shahzad, T. (2018). Heavy Metal Accumulation in Vegetables and Assessment of their Potential Health Risk. Journal of Environmental Analytical Chemistry, 5(1), 1000234-1000242. https://doi.org/10.4172/2380-2391.1000234

Ministry of Environment. (2009). Soil, ground water and sediment standards for use under part XV.1 of the environmental protection act. Ontario, Canada.

Nassif, N., \& Saade, Z. (2010). Studying heavy metals in sediments layers along selected sites on the Lebanese Coast. Journal of Water Resource and Protection, 2, 48-60. https://doi.org/10.4236/jwarp.2010.21006

Olowoyo, J. O., Okedeyi, O., Mkolo, N. M., Lion, G., \& Mdakane, S. T. R. (2011). Uptake and translocation of heavy metals by medicinal plants growing around a waste dump site in Pretoria, South Africa. South African Journal Botany, 78. https://doi.org/10.1016/j.sajb.2011.05.010

Rodrigues, S., Urquhart, G., Hossack, I., Pereira, M. A., Duarte, A. C., \& Davidson, C. (2009). The influence of anthropogenetic and natural geochemical factors of urban soil quality variability: A comparison between Glasgow, UK and Aveiro, Portugal. Environmental Chemistry Letters, 7, 141-8. https://doi.org/10.1007/ s10311-008-0149-y

Smith, L. A., Means, J. L., \& Chen, A. (1995). Remedial Options for Metals. Contaminated Sites, Lewis Publishers, Boca Raton, Fla, USA.

Su, C., Jiang, L., \& Zhang, W. (2014). A review on heavy metal contamination in the soil worldwide: Situation, impact and remediation techniques. Environmental Skeptics and Critics, 3(2), 24-38.

Zhai, Q., Narbad, A., Chen, W. (2015). Dietary strategies for the treatment of cadmium and lead toxicity. Nutrients, 7, 552-571. https://doi.org/10.3390/nu7010552

\section{Copyrights}

Copyright for this article is retained by the author(s), with first publication rights granted to the journal.

This is an open-access article distributed under the terms and conditions of the Creative Commons Attribution license (http://creativecommons.org/licenses/by/4.0/). 